\title{
Analytical procedures for the determination of estrogen compounds in a surface water reservoir in Southeast Brazil
}

Thayná Aparecida Cais $^{1} \mathbb{\oplus}^{\infty}$, Alley Michael da Silva Procópio ${ }^{1}{ }^{\infty}$, Márcia Matiko Kondo ${ }^{1}$, Flávio

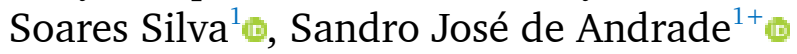

1.Universidade Federal de Itajubá Instituto de Física e Química, Itajubá, Minas Gerais, Brazil.

+Corresponding author: Sandro José de Andrade, Phone: +55 35-3629-1885, Email address: sandrojosedeandrade2020@gmail.com

\section{ARTICLE INFO}

Article history:

Received: April 28, 2019

Accepted: August 25, 2020

Published: January 01, 2021
Keywords
1. validation of analytical methodology
2. estrogens
3. endocrine disruptors
4. Furnas reservoir

\begin{abstract}
In this study, an analytical methodology was validated to determine and quantify four estrogen hormones using high-performance liquid chromatography (HPLC) with detections by diode array detector (DAD) and by fluorescence detector (FLD). For validation of the method, the following parameters were evaluated: linearity, selectivity, precision, accuracy, limit of detection (LOD), limit of quantification (LOQ) and robustness. Environmental samples were preconcentrated using solid phase extractions and for that, an experimental design was planned to determine the best recovery conditions by varying cartridge types, flow of eluent, $\mathrm{pH}$ of the samples, and eluting solvent.

Five surface water sampling campaigns were carried out in five different sites of Furnas Reservoir over the months of December 2015 and May 2016. Sample point 1 was located near the sewage treatment plant of the city of Alfenas - MG, while sample point 5 was the most distant from this location. All estrogens, except for E1, were found in all water samples of at least one of the sampling sites. The concentrations of E3, E2 and EE2 ranged from 11-366, 63422 and $75-9998 \mathrm{ng} \mathrm{L}^{-1}$, respectively. These results are consistent with several studies published in the scientific literature.

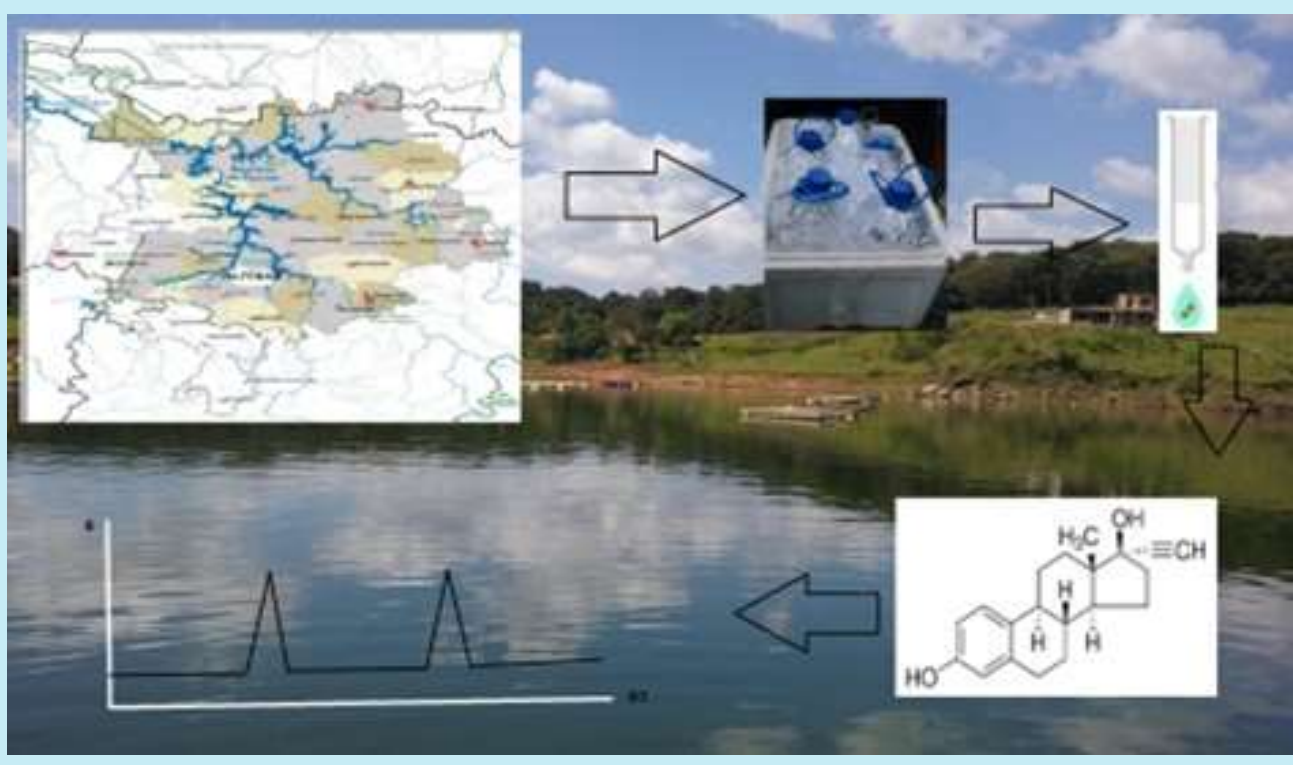

In this study, an analytical procedure was developed for the determination of estrogen compounds in water samples from Furnas reservoir, Alfenas - Minas Gerais (Brazil)
\end{abstract}




\section{Introduction}

Water is intrinsically linked to development in all societies and cultures. However, developments in agriculture, power generation and industry have brought major impacts to water resources ${ }^{1}$. Despite $\sim 71 \%$ of Earth's surface being covered by water, about $97.5 \%$ of this water is either saltwater, in oceans and seas, or unfit for human consumption. From the remaining $2.5 \%$, which constitutes freshwater, two thirds are stored in glaciers and polar ice caps. Therefore, only a fraction $(\sim 0.77 \%)$ of Earth's water is available for human consumption and is found in rivers, lakes, groundwaters, soils, atmosphere (humidity) and within the biota ${ }^{2}$. The continuous environmental degradation associated with the increase of human population (currently estimated in 7.2 billion and projected to reach 9-10 billion by 2050) suggests a significant decrease in life quality in a near future ${ }^{3,4}$. Because of the anthropogenic activity, a large volume of water, which would be available for consumption, is becoming contaminated with a large variety of toxic compounds. Among these pollutants, the Emerging Contaminants (EC) have been attracting a lot of attention from the scientific community. They are defined as any chemical compound present in a variety of commercial products, such as personal care, agrochemical, medicines for human and veterinary uses, food packages or any microorganisms found in environmental matrices that are not monitored nor regulated; however, pose potential risk to human health and environment safety ${ }^{5-10}$. A variety of EC are known as Endocrine Disruptors Compounds (EDC). These substances are of special concern because they interfere with the endocrine system, blocking or minimizing normal hormone functions, affecting synthesis or metabolism of many organisms ${ }^{11-15}$. The $17 \alpha-$ ethynylestradiol (EE2) is considered a potent endocrine disruptor ${ }^{15}$. This synthetic substance is used as a contraceptive or in hormone replacement therapies, it is often excreted via urine and feces by individuals taking the medication, eventually reaching water compartments ${ }^{16}$.

A variety of analytical methods and techniques can be used to detect and measure EDC from environmental matrices. The extraction approaches used more often are pressurized liquid extraction (PLE), quick-easy-cheap-effective-rugged-safe (QuEChERS), microwave-assisted extraction (MAE), ultrasonic-assisted extraction (UAE), stir-bar-sorptive extraction (SBSE), solid phase microextraction (SPME) and liquid-liquid extraction (LLE). For analyte enrichment and sample cleanup, solid phase extraction (SPE) with $\mathrm{C} 18$ cartridges ${ }^{17}$ are widely used. While for trace analysis of EDC, gas chromatography (GC) and liquid chromatography (LC $)^{17}$ are the dominant techniques.

Furnas is one of Brazil's largest water reservoirs with a flood area of 1,440 square kilometers, serving a population of approximately 800,000 inhabitants and irrigating 34 municipalities within the state of Minas Gerais $^{18}$. This reservoir is also of paramount economic importance within these municipalities, supporting activities such as fish farming - with about 500 farmers and over 5,000 tanks within the vicinity of the reservoir $^{19}$.

The aim of this study was to develop an analytical methodology to determine the presence of estrogen hormones in the Furnas reservoir, located in the region of the city of Alfenas (MG).

\section{Experimental}

\subsection{Reagents and solutions}

All reagents used were of high purity with spectroscopic or HPLC grades. Deionized water (resistivity $18.2 \mathrm{M} \Omega \mathrm{cm} 25{ }^{\circ} \mathrm{C}$ ) was taken from a Direct-Q (Millipore ${ }^{\circledR}$ ) purification system. The solvents methanol, acetonitrile (ACN), and ethyl acetate were purchased from Sigma-Aldrich (HPLC grade). Water and ACN filtrations were done using $0.45 \mu \mathrm{m}$ pore-size nylon and cellulose ester membranes, which were acquired from Millipore ${ }^{\circledR}$ and Supelco Analytical, respectively. The estrogen standards estrone (E3), estriol (E1), 17ß-estradiol (E2) and 17 $\alpha$ ethynylestradiol (EE2) were purchased from Fluka Analytical $^{\circledR}$ with purity greater than $99 \%$. Stock solutions of estrogens $\left(100 \mathrm{mg} \mathrm{L}^{-1}\right)$ were prepared in methanol, dissolving $0.0100 \mathrm{~g}$ of each commercial standard in a $100.00 \mathrm{~mL}$ volumetric flask. Standard working solutions $\left(10 \mathrm{mg} \mathrm{L}^{-1}\right)$ were prepared in $\mathrm{ACN}$ diluting $10.00 \mathrm{~mL}$ of the stock solution in a volumetric flask of $100.00 \mathrm{~mL}$. After prepared, these solutions were stored in polyethylene bottles at $4{ }^{\circ} \mathrm{C}$ and used as calibration standards.

\subsection{Validation of the analytical methodology}

The analytical methodology used was validated based on several works available in the literature and in the evaluation of the following figure of merits: selectivity, linearity, precision, accuracy, limit of detection, limit of quantification and robustness ${ }^{20-27}$. 
To confirm the selectivity of the method, estrogen standard solutions were prepared in acetonitrile at 1.00 $\mathrm{mg} \mathrm{L^{-1 }}$ and the spectral purity of each analyte was evaluated through chromatographic analysis. The linearity was verified by the linear coefficient of determination $\left(\mathrm{r}^{2}\right)$ resulting from the linear equation of nine and twelve points of the estrogen analytical curves, using DAD and FLD, respectively. For that, 12 mixed solutions were prepared from dilutions of the working solution in ACN at different concentrations (25 to $1000 \mu \mathrm{g} \mathrm{L}^{-1}$ ). Solutions preparation were performed in triplicate and the external standardization method was used. The sensitivity of the method was determined by evaluating the angular coefficient value derived from the linear equation of each estrogen calibration curve.

The limits of detection and quantification were determined through the signal-to-noise ratio, considering the ratio 3:1 and 10:1 for LOD and LOQ, respectively.

Since no Certified Reference Material (CRM) is available for water contaminated with the estrogens under study, fortified distilled water samples with a mixed solution containing the four estrogens were prepared in triplicates, at concentrations of $0.40,0.50$ and $0.60 \mu \mathrm{g} \mathrm{L}^{-1}$, extracted and injected into the HPLC system. Subsequently, method accuracy was evaluated through the recovery $(\mathrm{R})$ values of the analytes. For determination of the real concentration, the value of the peak area of each analyte and the corresponding linear equation was used. The recovery (in percentage) of each analyte was determined from the mean real concentration values.
To determine the accuracy of the method, six mixed solutions of $500 \mu \mathrm{g} \mathrm{L}^{-1}$ were prepared and injected into the HPLC system by analyst 1 . In the following day, the same procedure was performed by analyst 2 . It is worth mentioning that all samples were analyzed in triplicate. The recovery values found were expressed in percentage and evaluated using $\mathrm{F}$ tests. The values for $\mathrm{F}\left(\mathrm{F}_{\text {calculated }}\right)$ and $\mathrm{F}$ tabulated $\left(\mathrm{F}_{\text {tabulated }}\right)$ were compared with $95 \%$ of confidence level. The robustness of the method was evaluated by varying in $\pm 5 \%$ four chromatographic conditions: mobile phase composition, injection volume, flow rate of the mobile phase and temperature of the chromatographic column compartment. The obtained recovery values were compared to the ones achieved using normal conditions.

\subsection{Optimization of solid phase extraction (SPE)}

To verify the best SPE conditions for the analytes within the samples, a Box-Behnken design (BBD) was applied using Minitab $16^{\otimes}$ program. The planning was done with three levels: low (coded "-1"), central (code "0"), and high (coded “+1"), and four variables: cartridge types (Sorbline - C18, Chromabond - C18 and Strata-X - Polymeric resin), $\mathrm{pH}$ of water, flow rate of the eluent during extraction and elution solvent (Tab. 1). The total was 28 randomized experiments. During extractions, the conditions volume of water to be percolated $(1 \mathrm{~L})$, cartridge conditioning solvent (5.00 mL methanol) and cartridge wash solution (1.00 $\mathrm{mL}$ of water: $5 \%$ methanol) were invariable.

Table 1. Selected levels and factors in BBD.

\begin{tabular}{|l|c|c|c|}
\hline Factors & \multicolumn{2}{|c|}{ Levels } & $\mathbf{+ 1}$ \\
\hline Cartridge type & $\mathbf{- 1}$ & Chromabond & Strata-X \\
\hline pH of water & Sorbline & 6 & 8 \\
\hline Elution solvent & 4 & Methanol: Ethyl acetate $(1: 1)$ & Ethyl acetate \\
\hline Flow rate of mobile phase & Methanol & $5 \mathrm{~mL} \mathrm{~min}^{-1}$ & $10 \mathrm{~mL} \mathrm{~min}^{-1}$ \\
\hline
\end{tabular}

All extracted samples were prepared by fortifying 1 $\mathrm{L}$ of distilled water with $50.00 \mu \mathrm{L}$ of mixed estrogen working solution at $10 \mathrm{mg} \mathrm{L}^{-1}$. These samples were concentrated $(1000 \times)$ to produce a solution of $0.5 \mathrm{mg}$ $\mathrm{L}^{-1}$. This concentration was considered the central point of the analytical curves.

Then, sample $\mathrm{pH}$ was adjusted according to the experimental design, the adsorbent present in the cartridges was conditioned with $5.00 \mathrm{~mL}$ of methanol and the fortified water was percolated by the cartridge. The next step was the removal of interferents from the cartridge using $1.00 \mathrm{~mL}$ of wash solution and finally the extract was eluted with $5.00 \mathrm{~mL}$ of elution solvent, according to the planned BBD. The eluates were dried in a water bath at approximately $70{ }^{\circ} \mathrm{C}$, dissolved in $1.00 \mathrm{~mL}$ of ACN and sonicated in an ultrasonic bath for approximately $3 \mathrm{~min}$ for sample homogenization. Next, the samples were filtered through a $0.45 \mu \mathrm{m}$ pore-size filter and injected into the HPLC system, following the established chromatographic conditions. After performing the $28 \mathrm{BBD}$ experiments, the 
condition with the best performance (recovery) was selected.

\subsection{HPLC analysis}

The analyses were performed using an Agilent Technologies Infinity 1260 model chromatography system, consisting of a quaternary pump, an automatic injector, a column heating module, an ultraviolet detector with diode array and a molecular fluorescence detector. The acetonitrile and water, used as the mobile phase, were pre-filtered and degassed. In addition, an Eclipse Plus C8 $(4.6 \mathrm{~mm} \times 250 \mathrm{~mm}-5 \mathrm{~mm})$ chromatographic column was used. The optimum conditions for the chromatographic separation of these analytes are shown in Tab. 2.

Table 2. Optimized chromatographic conditions for analysis of estrogens using HPLC.

\begin{tabular}{|l|l|}
\hline Run time & $\mathbf{1 8 ~ m i n u t e s}$ \\
\hline Mobile phase composition & water:acetonitrile $-1: 1$ (isocratic mode) \\
\hline Flow rate of mobile phase & $0.5 \mathrm{~mL} \mathrm{m^{-1 }}$ \\
\hline Injection volume & $10 \mu \mathrm{L}$ \\
\hline Temperature of the chromatographic column & $40^{\circ} \mathrm{C}$ \\
\hline DAD wavelength detector & $285 \mathrm{~nm}$ \\
\hline FLD wavelength detector & $\lambda_{\text {excitation }}-230 \mathrm{~nm}$ e $\lambda_{\text {emission }}-310 \mathrm{~nm}$ \\
\hline
\end{tabular}

\subsection{Sampling sites}

Samplings were spatially and seasonally carried out between December 2015 and May 2016 in Lake Furnas within the municipality of Alfenas - MG - Brazil (Fig. 1), according to instructions from the National Guide for Collection and Preservation of Samples ${ }^{28}$ and with classifications of the National Water Agency ${ }^{29}$.

Samples were collected from 5 different sites (P1, P2, P3, P4 and P5). P1 was the closest to Alfenas' Sewage Treatment Station (STS); while P5 was the most distant sampling site from this STS (Fig. 2). With the assistance of a fisherman, each sampling was taken every $1 \mathrm{~km}$ using a boat. Samplings were made between $11 \mathrm{am}$ and $1 \mathrm{pm}$ and the coordinates of the sites were identified using a GPS.

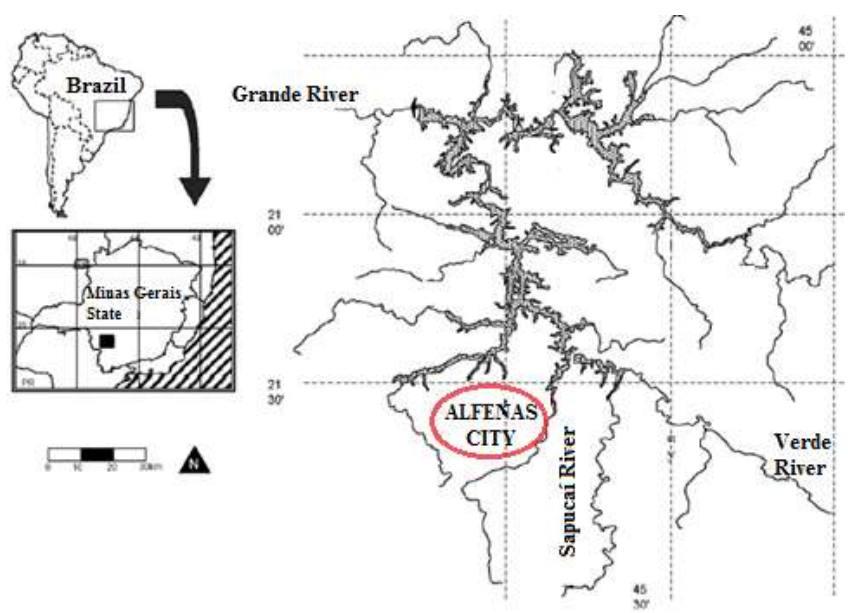

Figure 1. Map location of Lake Furnas and the municipality of Alfenas.

Source: Adapted from Prado et al. $(2011)^{30}$.

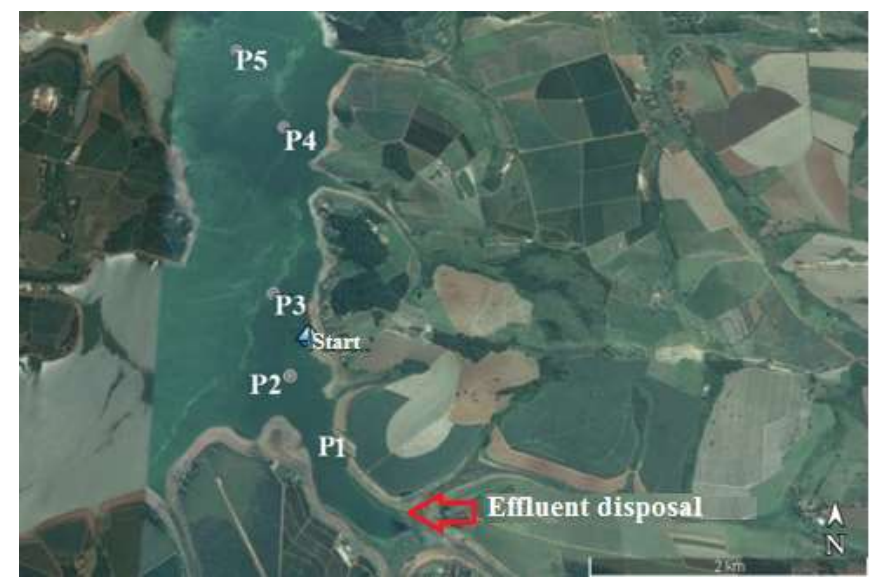

Figure 2. Sampling sites within Lake Furnas in the municipality of Alfenas.

Source: Google earth $(2020)^{31}$.

\subsection{Samplings}

Five liters of surface water were collected from each sampling site at a depth of $\sim 30 \mathrm{~cm}$, using a van Dorn bottle. The collected water was transferred to clean and acclimatized plastic bottles. Vials were sealed and transported in thermal containers to the laboratory where they were kept at $4{ }^{\circ} \mathrm{C}$. Starting from the second sampling campaign, temperature, $\mathrm{pH}$, conductivity and dissolved oxygen of the sampling site were measured in situ using a multiparameter probe (HI 9628 - pH/ORP/CE/DO).

\subsection{Sample preparation}

Samples from each sampling site were prepared in triplicate. A volume of $4 \mathrm{~L}$ was filtered several times through a Buchner funnel lined with qualitative filter 
paper (J. Prolab) and vacuum filtered in an enclosed glass system using $0.45 \mu \mathrm{m}$ pore-size cellulose acetate membrane (Agilent Technologies). After filtration, the $\mathrm{pH}$ of the samples was adjusted to 8 using $0.5 \mathrm{~mol} \mathrm{~L}^{-1}$ ammonium hydroxide solution whenever necessary. Subsequently, solid phase extractions were performed and elution was analyzed in the HPLC system.

\section{Results and discussion}

\subsection{Validation of the analytical methodology}

The proposed method was selective for both detectors. Even though the four studied estrogens have similar structures, satisfactory peak separation could be noticed in their chromatograms.

The linearity and sensitivity of the method were determined using linear regression analyses of the calibration curve from each estrogen, where coefficient of determination $\left(\mathrm{r}^{2}\right)$ and angular coefficient values were evaluated, as presented in Tab. 3 .

The methodology was linear for both detectors, the obtained $\mathrm{r}^{2}$ were above 0.98 and, according to Brito et $a l^{24}$, represent a strong correlation between peak areas and analyte's nominal concentrations. The validated method was more sensitive using the fluorescence detector (FLD) than the ultraviolet detector (DAD), since the first presented higher angular coefficients values.

Table 3. Retention time, equation of the line, linearity, and sensitivity of estrogens under study.

\begin{tabular}{|l|c|c|c|c|}
\hline Compounds & Retention time / min & Equation of the line & Linearity & Linear ranges / $\mu \mathbf{~ L ~}^{-\mathbf{1}}$ \\
\hline Estriol & 5.840 & $\mathrm{y}=15.388 \times-237.26$ & 0.9924 & $200-1000$ \\
\hline $17 \beta$-Estradiol & 10.640 & $\mathrm{y}=16.366 \times-526.74$ & 0.9885 & $200-1000$ \\
\hline $17 \alpha$-Ethynylestradiol & 12.513 & $\mathrm{y}=15.473 \times-682.62$ & 0.9854 & $200-1000$ \\
\hline Estrone & 13.860 & $\mathrm{y}=17.307 \times-693.63$ & 0.9895 & $200-1000$ \\
\hline Estriol $^{*}$ & 5.897 & $\mathrm{y}=27608 \times+66759$ & 0.9920 & $25-1000$ \\
\hline $17 \beta$ Estradiol $^{*}$ & 10.699 & $\mathrm{y}=28561 \times-79971$ & 0.9955 & $25-1000$ \\
\hline $17 \alpha$-Ethynylestradiol $^{*}$ & 12.578 & $\mathrm{y}=28047 \times-107662$ & 0.9989 & $25-1000$ \\
\hline
\end{tabular}

*Estrogens detected by fluorescence detector (FLD).

According to the limits of detection (LOD) and of quantification (LOQ), the estrogens under study could be detected and quantified at concentrations of as low as 200 and $300 \mu \mathrm{g} \mathrm{L}^{-1}$ for DAD and 25 and $50 \mu \mathrm{g} \mathrm{L}^{-1}$ for FLD. However, this methodology predicts sample preconcentration using SPE $(1000 \times)$; therefore, the LOD and LOQ of the method were 200 and $300 \mathrm{ng} \mathrm{L}^{-1}$ for DAD and 25 and $50 \mathrm{ng} \mathrm{L}^{-1}$ for FLD. The validated method using FLD can be considered more sensitive than when using DAD, since its values are lower.

The accuracy of the method was evaluated by mean recovery ( $\mathrm{R}_{\text {average }}$ ) and coefficient of variation $(\mathrm{CV})$ values. For estrogens detected using $\mathrm{DAD}, \mathrm{R}_{\text {average }}$ ranged from $62.1-101.2 \%$ with $\mathrm{CV}$ of less than $15 \%$. When using FLD, $\mathrm{R}_{\text {average }}$ ranged from 80.0-105.6\% with CV of less than $7.0 \%$. These values are considered satisfactory, since the acceptable recovery values for samples at concentrations of $\mathrm{ng} \mathrm{L}^{-1}$ are between $40-120 \%$ with $\mathrm{CV}$ of less than $45 \%{ }^{24}$.

The criteria employed to evaluate the method precision was based on the comparison of experimental and tabulated values of the $\mathrm{F}$ test for two sets of samples $(\mathrm{n}=6$ each set). Table 4 shows the mean recovery $\left(\mathrm{R}_{\text {average }}\right)$, coefficient of variation $(\mathrm{CV})$, $\mathrm{F}_{\text {calculated }}$ and $\mathrm{F}_{\text {tabulated }}$ values for the datasets prepared by analysts 1 and 2 .

The validated methodology proved to be accurate because, in all cases, $F_{\text {cal }}<F_{\text {tab }}$. There is no significant difference between the values of variance with $95 \%$ of credibility, since the in the values of $F_{\text {tabulated, }}$ for a degree of freedom of 5 , both denominator and numerator are equal to $5.05^{22}$.

The method showed to be robust against variations in mobile phase composition, injection volume, flow rate of the mobile phase and chromatographic column compartment temperature. The mean recovery $\left(\mathrm{R}_{\text {average }}\right)$ values for the analytes using DAD were between 70.7$118.7 \%$ with a coefficient of variation (CV) of less than $10.6 \%$. On the other hand, when using FLD the $\mathrm{R}_{\text {average }}$ were between $91.0-108.8 \%$ with $\mathrm{CV}$ of less than $4.8 \%$. The values obtained are within acceptable ranges; therefore, none of the alterations done to the chromatographic parameters showed significant effect on the recovery of the estrogens. 
Table 4. Average recovery $\left(\mathrm{R}_{\text {average }}\right)$, coefficient of variation $(\mathrm{CV}), \mathrm{F}_{\text {calculated, and }} \mathrm{F}_{\text {tabulated }}$ values for the data sets prepared by analysts 1 and 2 .

\begin{tabular}{|c|c|c|c|c|c|c|c|}
\hline & \multicolumn{4}{|c|}{ Estrogen detected by DAD } & \multicolumn{3}{|c|}{ Estrogen detected by FLD } \\
\hline & $\mathbf{E 3}$ & $\mathbf{E 2}$ & EE2 & E1 & $\mathbf{E 3}$ & $\mathbf{E 2}$ & EE2 \\
\hline $\begin{array}{l}\text { Analyst } 1 \\
\mathrm{R}_{\text {average }}(\%) \pm \text { standard deviation }\end{array}$ & $101 \pm 7$ & $112 \pm 7$ & $101 \pm 7$ & $104 \pm 8$ & $105 \pm 1$ & $107 \pm 2$ & $100 \pm 2$ \\
\hline $\begin{array}{l}\text { Analyst } 2 \\
\mathrm{R}_{\text {average }}(\%) \pm \text { standard deviation }\end{array}$ & $109 \pm 8$ & $111 \pm 10$ & $108 \pm 5$ & $105 \pm 8$ & $108 \pm 2$ & $102 \pm 2$ & $102 \pm 3$ \\
\hline CV (\%) Analyst 1 & 6.8 & 6.3 & 7.3 & 10.4 & 0.6 & 1.6 & 2.1 \\
\hline CV (\%) Analyst 2 & 7.3 & 8.8 & 4.7 & 7.3 & 4.3 & 5.2 & 5.4 \\
\hline$F_{\text {calculated }}$ & 1.3 & 1.9 & 2.2 & 1.0 & 3.2 & 1.6 & 2.1 \\
\hline $\mathrm{F}_{\text {tabulated }}$ & 5.05 & 5.05 & 5.05 & 5.05 & 5.05 & 5.05 & 5.05 \\
\hline
\end{tabular}

\subsection{Optimization of solid phase extraction (SPE) conditions}

After performing the $28 \mathrm{BBD}$ experiments, extracts were analyzed in a HPLC system and the average recovery of all detected analytes of each experiment was calculated. In some cases, the mean recovery exceeded the acceptable range for recovery of analytes at ng $\mathrm{L}^{-1}$ (40-120\%), which may be related to coelution of impurities presented within the cartridge.

The mean recovery data were used to obtain response surface graphs, corelating mean recovery values in the $\mathrm{Z}$ axis and two other variables (coded as 1,0 and +1 ) in $\mathrm{X}$ and $\mathrm{Y}$ axes, using the software Statistica 2010. The related response surface graph variables were cartridge versus $\mathrm{pH}$ of water, cartridge versus elution solvent, cartridge versus flow rate of the eluent during the extraction, $\mathrm{pH}$ of water versus elution solvent, $\mathrm{pH}$ of water versus flow rate of the eluent during the extraction and elution solvent versus flow rate of the eluent during the extraction.

With regards to the flow rate of the eluent during the extraction versus cartridge type variable, it can be noticed that the lower the flow rate, the greater is the recovery, since the longer the sample stays in contact with the solid phase of the cartridge higher the chances of interactions between analytes and adsorbent phase.

Most BBD experiments presented recovery values within acceptable range for both detectors. However, according to the response surface graphs and the most satisfactory recovery values, it was opted to keep with the parameters used in the experiment number 5 , which presents the following conditions: brand cartridge Chromabond C18-ec; $\mathrm{pH}$ of water equal to 8; Methanol: Ethyl acetate (1:1) as elution solvents; and flow rate of the eluent during the extraction of $3 \mathrm{~mL}$ $\min ^{-1}$.

\subsection{Estrogens determination in Lake Furnas, Alfenas-MG}

\subsubsection{Some physical-chemical characteristics of water within the sampling sites}

To test if Lake Furnas is in accordance with the environmental standards determined by Resolution National Council of the Environment (CONAMA) $357 / 2005^{30}, \mathrm{pH}$, conductivity, temperature; and dissolved oxygen within the vicinity of each sampling site were measured. Maximum and minimum values for each sampling sites are shown in Tab. 5 .

According to the CONAMA Resolution 357/2005, Furnas Lake is classified as a class II river with $\mathrm{pH}$ values between $6.16-8.36$. Therefore, within the permitted values (6.0 to 9.0 ).

The dissolved oxygen (OD) in water, which is essential for survival of aerobic organisms, according to this same legislation, should be higher than $5 \mathrm{mg} \mathrm{L}^{-1}{ }^{32}$. In this term, the samplings that occurred in 04/28/16 and 05/19/16 presented values below the permitted level. This may be related to an environmental incident occurred in 05/01/16, where tons of tilapia, within tanks-nets, were found dead. According to the Environmental Military Police and professors from the University of Alfenas, the lack of sun-light and extended drought period contributed to the OD decrease, which may have caused the death of red algae and subsequent release of toxins to the surrounding water, aggravating fish mortality ${ }^{33}$. In a similar incident in 2013, also because of the drought, the level of the Lake lowered. After this period, with the increase of rain and temperature, there was a critical algae proliferation, causing drastic OD reduction, culminating in fish mortality again ${ }^{34}$. According to Tab. 5, temperatures within Lake Furnas varied from 23.98 to $29.21{ }^{\circ} \mathrm{C}$, possibly indicating normal seasonal variations. 
According to the CETESB specifications ${ }^{35}$, conductivity values higher than $100 \mu \mathrm{S} \mathrm{cm} \mathrm{cm}^{-1}$ could indicate that environments were impacted. In Lake Furnas, the measurements were well below this limit, indicating the region may not present high pollution loads.

In addition to these physical-chemical characteristics, turbidity of the water samples was also measured. According to the CONAMA Resolution $357 / 2005^{32}$, turbidity values for a class 2 river should stay below 100 Nephelometric Turbidity Unit (NTU). Values above this limit may indicate a constant load of pollutants within the area. The measured values were lower than 6.0 NTU, indicating the sample sites have reduced turbidity.

Table 5. Maximum and minimum values of $\mathrm{pH}$, dissolved oxygen, temperature- and conductivity measured in the surroundings of collection sites.

\begin{tabular}{|l|c|c|c|c|}
\hline Sampling date & $\mathbf{p H}$ & Dissolved oxygen $/ \mathbf{m g ~ L}^{-\mathbf{1}}$ & Temperature $/{ }^{\circ} \mathbf{C}$ & ${\text { Conductivity } / \boldsymbol{\mu S} \mathbf{~ c m}^{-1}}^{-1}$ \\
\hline $09-03-2016$ & $6.16-7.11$ & $5.07-5.65$ & $27.96-28.31$ & $20-27$ \\
\hline $07-04-2016$ & $7.61-8.36$ & $6.99-8.14$ & $28.23-29.21$ & $30-33$ \\
\hline $28-04-2016$ & $6.42-6.77$ & $3.44-4.60$ & $26.63-27.03$ & $14-22$ \\
\hline $19-05-2016$ & $6.29-6.44$ & $2.77-3.75$ & $23.98-24.25$ & $28-39$ \\
\hline
\end{tabular}

\subsubsection{SPE and chromatographic analysis of} samples collected at Furnas Lake

The SPE of water samples were carried out at a flow rate of $3 \mathrm{~mL} \mathrm{~min} \mathrm{~m}^{-1}$, proceeding was as follows: adjusting the $\mathrm{pH}$ of the sample to 8 , conditioning the cartridge with $5.00 \mathrm{~mL}$ of methanol and passing $1 \mathrm{~L}$ of the sample through the cartridge. After percolation of the sample, the cartridge was washed with $1.00 \mathrm{~mL}$ of wash solution (water: 5\% methanol) and the analytes were eluted with $5.00 \mathrm{~mL}$ of methanol: ethyl acetate to the cartridge. Subsequently, the eluates were dried in a water bath at $70{ }^{\circ} \mathrm{C}$ using a heating mantle, resuspended in $1.00 \mathrm{~mL}$ of acetonitrile, placed in an ultrasonic bath for $3 \mathrm{~min}$, filtered with $0.45 \mu \mathrm{m}$ pore- size filters and injected into the HPLC system. The fluorescence detector was more sensitive, had lower detection and quantification limits, and recovery values closer to $100 \%$ when compared to the validated methodology. Therefore, it was decided to analyze all estrogens, except estrone, which was detected only by DAD using the validated method.

It can be observed that the analytes presented good separation and the retention times obtained are close to the values obtained in the validation of the analytical methodology employed. It is worth mentioning that estrone was not found in any of the samples collected, therefore, no chromatogram showing this estrogen was obtained.

Table 6. Mean concentration and standard deviation found for estriol, $17 \beta$-estradiol and $17 \alpha$-ethynylestradiol in the water samples collected in the study region.

\begin{tabular}{|c|c|c|c|c|c|c|}
\hline \multirow{2}{*}{ Sampling / date } & \multirow{2}{*}{ Estrogen } & \multicolumn{5}{|c|}{ Sampling site average recovery / $\mathrm{ng} \mathrm{L}^{-1} \pm$ standard deviation } \\
\hline & & 1 & 2 & 3 & 4 & 5 \\
\hline \multirow[t]{3}{*}{$1(12 / 07 / 2015)$} & E3 & ND & ND & ND & $202 \pm 9$ & $237 \pm 11$ \\
\hline & E2 & $76 \pm 1$ & $75 \pm 1$ & $101 \pm 1$ & $* 1732 \pm 9$ & $* 2089 \pm 7$ \\
\hline & EE2 & ND & ND & ND & $322 \pm 10$ & $320 \pm 11$ \\
\hline \multirow[t]{3}{*}{$2(03 / 09 / 2016)$} & E3 & ND & $<\mathrm{LOQ}$ & $157 \pm 5$ & $366 \pm 5$ & $181 \pm 14$ \\
\hline & E2 & $154 \pm 4$ & $116 \pm 1$ & $124 \pm 1$ & $* 9998 \pm 3$ & $195 \pm 3$ \\
\hline & EE2 & ND & ND & $118 \pm 1$ & $209 \pm 5$ & $196 \pm 4$ \\
\hline \multirow{3}{*}{$3(04 / 07 / 2016)$} & E3 & $318 \pm 3$ & $208 \pm 7$ & $182 \pm 1$ & $120 \pm 1$ & $110 \pm 3$ \\
\hline & E2 & $* 2536 \pm 1$ & $* 1993 \pm 1$ & $* 1792 \pm 1$ & $* 1415 \pm 1$ & $* 1066 \pm 1$ \\
\hline & EE2 & $422 \pm 5$ & $284 \pm 3$ & $256 \pm 10$ & $180 \pm 2$ & $141 \pm 1$ \\
\hline \multirow[t]{3}{*}{$4(04 / 28 / 2016)$} & E3 & $153 \pm 18$ & ND & ND & ND & ND \\
\hline & E2 & $* 1101 \pm 0.0$ & $411 \pm 7$ & $436 \pm 2$ & $236 \pm 1$ & $231 \pm 1$ \\
\hline & EE2 & $143 \pm 4$ & $67 \pm 3$ & $63 \pm 2$ & $<\mathrm{LOQ}$ & $<\mathrm{LOQ}$ \\
\hline \multirow[t]{3}{*}{$5(05 / 19 / 2016)$} & E3 & ND & ND & ND & ND & ND \\
\hline & E2 & $321 \pm 2$ & $183 \pm 3$ & $254 \pm 1$ & $194 \pm 1$ & $206 \pm 1$ \\
\hline & EE2 & $76 \pm 0.0$ & $<$ LOQ & $<\mathrm{LOQ}$ & $<$ LOQ & $<\mathrm{LOQ}$ \\
\hline
\end{tabular}

*Samples that were diluted 10 times to understand the concentration range of the analytical curve of the validated method; ND $=$ Not Detected. 
The results presented in Tab. 6 refer to the average concentrations for each estrogen found in the five collection points during the five sampling campaigns conducted between December 2015 and May 2016.

In general, the results in Tab. 6 show that each water sample analyzed was positive for at least one of the tested estrogens. 17 $\beta$-estradiol (E2) was detected and quantified in all samples, while Estriol (E3) and 17 $\alpha$-ethynylestradiol (EE2) were detected in 48 and $80 \%$ of the samples, respectively. The maximum concentrations determined were: E3 $366 \pm 5$; E2 9998 \pm 3 ; and EE2 $422 \pm 5 \mathrm{ng} \mathrm{L}^{-1}$. Estrone (E1) was neither detected nor quantified by the employed optimized analytical methodology (Fig. 3). However, since E2 is oxidized to E1 after excretion and because of the high E2 concentration found, E1 might also be present in Furnas Lake. On the other hand, due to the sorption coefficient value of estrone (4882), the highest among these four estrogens, a high sorption potential can be expected in soils and sediments, which would reduce their concentration within the water column ${ }^{36-38}$.

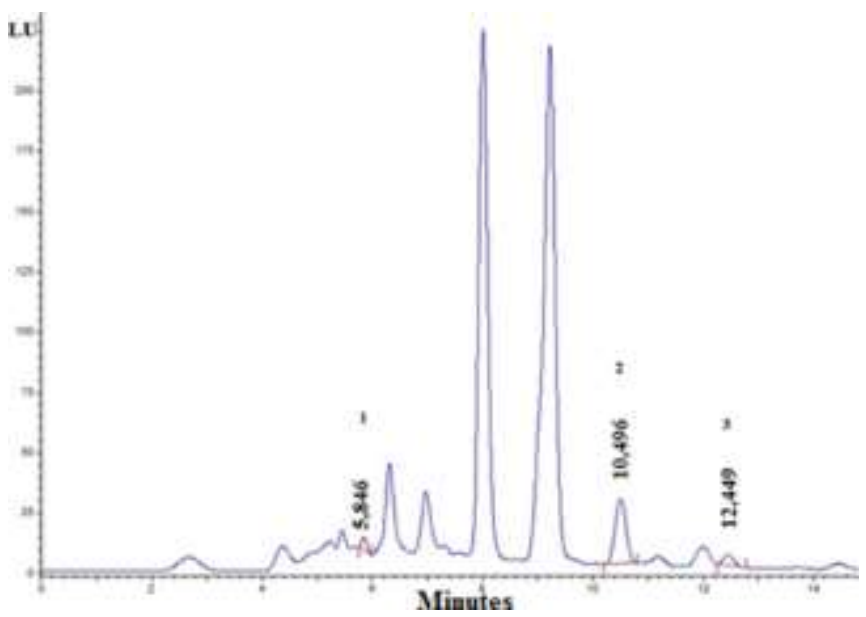

Figure 3. Chromatogram of one of the water samples collected in Lake Furnas concerning the separation of estrogens with FLD detection: 1) estriol; 2) 17ß-estradiol; 3) $17 \alpha$-ethynylestradiol.

One possible explanation for the absence of estrogens in some of the analyzed water samples would be their presence in the conjugated form, basically in the form of sulfates and glucuronides. These polar conjugates are biologically inactive and more soluble in water when compared to their corresponding unconjugated counterparts. Therefore, to monitor the presence of these estrogens in this form, a specific analytical method would be required.

Similar results to these presented in the current study were reported by Montagner and Jardim ${ }^{39}$. An analytical method was optimized for determination of
15 emerging contaminants within surface waters from the Atibaia River, in the city of Campinas (SP - Brazil), using solid phase extraction and high-performance liquid chromatography with ultraviolet detection with diode array and fluorescence. The method was applied for spatial and seasonal monitoring of these emerging contaminants, which included estrone (E1), 17 $\beta$ estradiol (E2) and 17 $\alpha$-ethynylestradiol (EE2). Among these, E2 was the most frequently detected, present in $35 \%$ of the 26 samples and found in high concentrations, which ranged from 106-6806 $\mathrm{ng} \mathrm{L}^{-1}$. On the other hand, EE2 was found in only three samples and E1 was not detected.

Many studies in the literature report the determination of these estrogens; however, they were detected in lower concentrations when compared to those in this study. Monteiro and Andrade ${ }^{40}$ developed and validated an analytical methodology for determination of the synthetic estrogens levonorgestrel (LNG) and 17 $\alpha$-ethynylestradiol (EE2) in surface waters of the Sapucaí River, in Itajubá (MG - Brazil). Samplings were carried out within the urban region of the river during the rainy season. EE2 was found in the 5 sampling sites at concentrations ranging from 67.4$99.1 \mathrm{ng} \mathrm{L}^{-1}$, whereas LNG was not found in any sampling site. In Belo Horizonte (MG, Brazil), Moreira et $a l .{ }^{41}$ analyzed water samples from the river called Rio das Velhas, Morro Redondo and Vargem das Flores lake, and determined concentrations between 1.5-36.8 $\mathrm{ng} \mathrm{L}^{-1}$ for $17 \beta$-estradiol and 3.0-54 $\mathrm{ng} \mathrm{L}^{-1}$ for $17 \alpha$-ethynylestradiol within these samples. Other authors reported lower concentrations of E2 ( 0.3 and $\left.1.3 \mathrm{ng} \mathrm{L}^{-1}\right)$ and EE2 (0.5 and 3,0 $\left.0 \mathrm{ng} \mathrm{L}^{-1}\right)$ form groundwater samples in Rhône-Alpes region

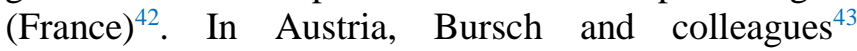
evaluated 27 surface water and 59 groundwater samples, totaling 261 and 112, respectively. In more than $50 \%$ of surface water samples, E2 and E1 were detected at low concentrations (average of 0.13 and $0.35 \mathrm{ng} \mathrm{L} \mathrm{L}^{-1}$, respectively). While in groundwater samples, E2 was detected in 50\% of samples with a maximum value of $0.79 \mathrm{ng} \mathrm{L}^{-1}$.

In contrast, some studies in Brazil and in other countries found these estrogens in concentrations even higher than the reported here. In analysis of surface water samples from the city of Campinas (SP - Brazil), the identified concentrations of E1, E2; and EE2 were in $\mu \mathrm{g} \mathrm{L}^{-1}$ scales, ranging from 3.5-5.0, 1.9-6.0 and 1.23.5 , respectively ${ }^{44}$. Daniel and Lima ${ }^{45}$ tested for the presence of estrogen, estriol, 17 $\beta$-estradiol; and $17 \alpha$ ethynylestradiol in water samples from the Tubarão River, in the border of municipalities of Santo André and Mauá (SP - Brazil). In this study, significant 
concentrations of estriol $\left(0.4 \mathrm{~g} \mathrm{~L}^{-1}\right)$ and estrone $(0.32 \mathrm{~g}$ $\left.\mathrm{L}^{-1}\right)$ were detected. Chaves ${ }^{46}$ validated an analytical method and used SPE and HPLC-UV for determination of endocrine disruptors BFA, E2, EE2 and E1 in the Paraíba do Sul River, Aparecida (SP - Brazil). In the work, surface water samples were taken at different depths, close to the water collection point for public supply, which is located $50 \mathrm{~m}$ downstream from the sewage disposal site of the National Sanctuary of Aparecida. High concentrations were found for all analytes, ranging from $0.032-0.088 \mu \mathrm{g} \mathrm{L}^{-1}$ for BFA, $0.009-0.40 \mu \mathrm{g} \mathrm{L}^{-1}$ for E2, 0.07-0.6 $\mu \mathrm{g} \mathrm{L}^{-1}$ for EE2 and $0.107-0.91 \mu \mathrm{g} \mathrm{L}^{-1}$ for E1. The author inferred that the values obtained may be associated with the number of visitors in the city, the inefficiency of conventional sewage treatment system to remove such contaminants, rainfall index and temperature. Since these endocrine disruptors may represent risks to biota at concentrations of as low as ng $\mathrm{L}^{-1}$, such exposures at $\mu \mathrm{g} \mathrm{L}^{-1}$ and $\mathrm{g} \mathrm{L}^{-1}$ scales, are even more alarming.

The works described above confirm that the results found for Furnas Lake in Alfenas is not a particular case and show that rivers from different parts of Brazil are contaminated with endocrine disruptors.

\section{Conclusions}

The validated analytical methodology for monitoring estrone, estriol, $17 \beta$-estradiol and $17 \alpha-$ ethynylestradiol was adequate, according to the evaluated figures of merit. In view of the responses obtained with the fluorescence detector (FLD), such as high sensitivity, optimal values of recovery and low LOQ and LOD, it was decided to work with this detector for all estrogens, except estrone, which was only detected by DAD.

The use of chemometric methods for experimental design and data processing was efficient. Considering this and the analysis of response surface plots, it was possible to determine the best performing experiment to extract the four studied estrogens.

The five sampling campaigns were carried out from December 2015 to May 2016 in 5 different sites. In general, all estrogens were found in all samples of at least one of these collection points, only E1 was not. Concentrations of E3, E2 and EE2 ranged from 11-366, 75-9998, and 63-422 $\mathrm{ng} \mathrm{L}^{-1}$, respectively.

In view of the results obtained, it would be interesting to deepen further studies on this topic and to develop and validate analytical methodologies for estrogen determination in their conjugated forms. Additionally, other emerging contaminants could also be analyzed within this same studied region as in other parts of Furnas Lake, since this subject has been neglected by the scientific community until the present moment.

\section{Acknowledgments}

The authors would like to acknowledge financial support from the following Brazilian Research agencies: CAPES CNPq and FAPEMIG.

\section{References}

[1] United Nations Educational, Scientific and Cultural Organization (UNESCO). Water for a sustainable world. 2015.

http://unesdoc.unesco.org/images/0023/002318/231823E.pdf

[2] Grassi, M. T. As águas do planeta Terra, Cadernos Temáticos de Química Nova na Escola 1 (1) (2001) 31-40. http://qnesc.sbq.org.br/online/cadernos/01/aguas.pdf.

[3] Avigliano, E., Schenone, N. F., Human health risk assessment and environmental distribution of trace elements, glyphosate, fecal coliform and total coliform in Atlantic Rainforest mountain rivers (South America), Microchemical Journal $122 \quad$ (2015) 149-158. https://doi.org/10.1016/j.microc.2015.05.004.

[4] United States Census Bureau (USCB), International Data Base (IDB). U.S. and World Population Clock Census Bureau, Washington, 2015. http://www.census.gov/popclock/.

[5] Silva, C. G. A., Collins, C. H., Aplicações de cromatografia líquida de alta eficiência para o estudo de poluentes orgânicos emergentes, Química Nova 34 (4) (2011) 665-676. https://doi.org/10.1590/S010040422011000400020 .

[6] Deblonde, T., Cossu-Leguille, C., Hartemann, P., Emerging pollutants in wastewater: A review of the literature, International Journal of Hygiene and Environmental Health $214 \quad$ (6) (2011) 442-448. https://doi.org/10.1016/j.ijheh.2011.08.002.

[7] Jurado, A., Vàzquez-Suñé, E., Carrera, J., Alda, M. L., Pujades, E., Barceló, D., Emerging organic contaminants in groundwater in Spain: A review of sources, recent occurrence and fate in a European context, Science of The Total Environment $440 \quad$ (2012) 82-94. https://doi.org/10.1016/j.scitotenv.2012.08.029.

[8] Luo, Y., Guoa, W, Ngo, H. H., Nghiem, L. D., Hai, F. I., Zhang, J., Liang, S., Wang, X. C., A review on the occurrence of micropollutants in the aquatic environment and their fate and removal during wastewater treatment, 
Science of The Total Environment 473-474 (2014) 619-641. https://doi.org/10.1016/j.scitotenv.2013.12.065.

[9] Braz, F. S., Silva, M. R. A., Silva, F. S., Andrade, S. J., Fonseca, A. L., Kondo, M. M., Photocatalytic Degradation of Ibuprofen Using $\mathrm{TiO}_{2}$ and Ecotoxicological Assessment of Degradation Intermediates against Daphnia similis, Journal of Environmental Protection 5 (7) (2014) 620-626. https://doi.org/10.4236/jep.2014.57063.

[10] Candido, J. P., Andrade, S. J., Fonseca, A. L., Silva, F. S., Silva, M. R. A., Kondo, M. M., Ibuprofen removal by heterogeneous photocatalysis and ecotoxicological evaluation of the treated solutions, Environmental Science and Pollution Research 23 (2016) 19911-19920. https://doi.org/10.1007/s11356-016-6947-z.

[11] Barreiros, L., Queiroz, J. F., Magalhães, L. M., Silva, A. M. T., Segundo, M. A., Analysis of 17- $\beta$-estradiol and 17- $\alpha-$ ethinylestradiol in biological and environmental matrices A review, Microchemical Journal 126 (2016) 243-262. https://doi.org/10.1016/j.microc.2015.12.003.

[12] Mei, S., Wu, D., Jiang, M., Lu, B., Lim, J.-M., Zhou, Y.-K., Lee, Y.-I., Determination of trace bisphenol A in complex samples using selective molecularly imprinted solid-phase extraction coupled with capillary electrophoresis, Microchemical Journal 98 (1) (2011) 150155. https://doi.org/10.1016/j.microc.2011.01.003.

[13] Giulivo, M., Alda, M. L., Capri, E., Barceló, D., Human exposure to endocrine disrupting compounds: Their role in reproductive systems, metabolic syndrome and breast cancer. A review, Environmental Research 151 (2016) 251264. https://doi.org/10.1016/j.envres.2016.07.011.

[14] Diamanti-Kandarakis, E., Bourguignon, J.-P., Giudice, L. C., Hauser, R., Prins, G. S., Soto, A. M., Zoeller, R. T., Gore, A. C., Endocrine-disrupting chemicals: an endocrine society scientific statement, Endocrine Reviews 30 (4) (2009) 293-342. https://doi.org/10.1210/er.2009-0002.

[15] Nohynek, G. J., Borgert, C. J., Dietrich, D., Rozman, K. K. Endocrine disruption: fact or urban legend? Toxicology Letters $223 \quad$ (3) 295-305. https://doi.org/10.1016/j.toxlet.2013.10.022.

[16] Leonard, J. A., Cope, W. G., Hammer, E. J., Barnhart, M. C., Bringolf, R. B., Extending the toxicity-testing paradigm for freshwater mussels: Assessing chronic reproductive effects of the synthetic estrogen $17 \alpha-$ ethynylestradiol on the unionid mussel Elliptio complanata, Comparative Biochemistry and Physiology Part C: Toxicology \& Pharmacology $191 \quad$ (2017) 14-25. https://doi.org/10.1016/j.cbpc.2016.09.002.

[17] Omar, T. F. T., Ahmad, A., Aris, A. Z., Yusoff, F. M. Endocrine disrupting compounds (EDCs) in environmental matrices: Review of analytical strategies for pharmaceuticals, estrogenic hormones, and alkylphenol compounds, TrAC Trends in Analytical Chemistry 85 (Part C) (2016) 241-259. https://doi.org/10.1016/j.trac.2016.08.004.

[18] Instituto Brasileiro de Geografia e Estatística (IBGE). Censo demográfico de 2009. http://censo2010.ibge.gov.br/.

[19] Instituto Mineiro de Gestão das Águas (IGAM). Plano Diretor de Recursos Hídricos da Bacia Hidrográfica do Entorno do Lago de Furnas, Alfenas. http://www.igam.mg.gov.br/gestao-das-aguas/plano-derecursos-hidricos.

[20] Amarante Junior, O. P., Caldas, E. P. A., Brito, N. M., Santos, T. C. R., Vale, M. L. B. F., Validação de métodos analíticos: uma breve revisão, Cadernos de Pesquisa. 12 (12) (2001) 116-131. https://docplayer.com.br/39827741Validacao-de-metodos-analiticos-uma-breve-revisao.html.

[21] Agência Nacional de Vigilância Sanitária (ANVISA). Resolução n 899, de 29 de maio de 2003. http://bvsms.saude.gov.br/bvs/saudelegis/anvisa/2003/res089 9_29_05_2003.html.

[22] Baccan, N., Andrade, J. C., Godinho, O. C. S., Barone, J. S. Química Analítica Quantitativa Elementar. Edgard Blucher, São Paulo, 3rd ed., 2001.

[23] Amarante Junior, O. P., Polese, L., Santos, T. C. R., Ribeiro, M. L. Avaliação da exatidão e da precisão de métodos de análise de resíduos de pesticidas mediante ensaios de recuperação, Pesticidas: Revista de Ecotoxicologia e Meio Ambiente 12 (2002) 155-168. https://doi.org/10.5380/pes.v12i0.3157.

[24] Brito, N. M., Amarante Junior, O. P., Polese, L., Ribeiro, M. L., Validação de métodos analíticos: estratégia e discussão, Pesticidas: Revista de Ecotoxicologia e Meio $\begin{array}{llll}\text { Ambiente } & 13 & \text { (2003) } & \text { 129-146. }\end{array}$ https://doi.org/10.5380/pes.v13i0.3173.

[25] Instituto Nacional de Metrologia, Normalização e Qualidade Industrial (INMETRO). Orientações sobre Validação de Métodos de Ensaios Químicos DOQ-CGCRE008,

2010 . http://www.inmetro.gov.br/Sidoq/Arquivos/Cgcre/DOQ/DO Q-Cgcre-8_05.pdf.

[26] Ribani, M., Bottoli, C. B. G., Collins, C. H., Jardim, I. C. S. F., Melo, L. F. C., Validação em métodos cromatográficos e eletroforéticos, Química Nova 27 (5) (2004) 771-780. https://doi.org/10.1590/S010040422004000500017 .

[27] Ribani, M., Collins, C. H., Bottoli, C. B. G., Desenvolvimento e validação de método para separação de isoflavonas em extrato seco de soja, Ciência e Natura 36 (3) (2014) 501-510. https://doi.org/10.5902/2179460X12817. 
[28] Companhia Ambiental do Estado de São Paulo (CETESB), Agência Nacional de Água (ANA). Guia Nacional de Coleta e Preservação de Amostras: água, sedimentos, comunidades aquáticas e efluentes líquidos. CETESB, ANA, Brasília, 2011. https://arquivos.ana.gov.br/institucional/sge/CEDOC/Catalo go/2012/GuiaNacionalDeColeta.pdf.

[29] Agência Nacional de Água (ANA). Boletim de Monitoramento do Reservatório de Furnas. Brasília, 3 (12) (2015) $1-13$. https://arquivos.ana.gov.br/saladesituacao/BoletinsMensais/F urnas/Boletim_Monitoramento_Furnas_2015_12.pdf.

[30] PRADO, P. S.; SOUZA, C. C.; BAZZOLI, N.; RIZZO, E. Reproductive disruption in lambari Astyanax fasciatus from a Southeastern Brazilian reservoir. Ecotoxicology and Environmental Safety 74 (2011), 1879-1887. https://doi.org/10.1016/j.ecoenv.2011.07.017.

\section{[31] GOOGLE EARTH,}

https://www.google.com.br/intl/pt-BR/earth/.

2020.

[32] Brasil. Conselho Nacional do Meio Ambiente (CONAMA). Resolução n. 357 de 17 de março de 2005. Dispõe sobre a classificação dos corpos de água e diretrizes ambientais para o seu enquadramento, bem como estabelece as condições e padrões de lançamento de efluentes, e dá outras providências. 2005. http://www2.mma.gov.br/port/conama/legiabre.cfm?codlegi $=459$.

[33] G1-Sul de Minas. Falta de sol pode ter contribuído para morte de peixes no Lago de Furnas. 2016. http://g1.globo.com/mg/sul-de-minas/noticia/2016/05/faltade-sol-pode-ter-contribuido-para-morte-de-peixes-no-lagode-furnas.html.

[34] Globo Rural. Mortandade de peixes no Lago de Furnas (MG) prejudica criadores. 2013. http://globoplay.globo.com/v/2451854/.

[35] Companhia de Tecnologia de Saneamento Ambiental (CETESB). Significado ambiental e sanitário das variáveis de qualidade das águas e dos sedimentos e metodologias analíticas e de amostragem. Série de relatórios: Qualidade das águas interiores no estado de São Paulo. p.43, 2009.

[36] Dolar, D., Gros, M., Rodriguez-Mozaz, S., Moreno, J., Comas, J., Rodriguez-Roda, I., Barceló, D., Removal of emerging contaminants from municipal wastewater with an integrated membrane system, MBR-RO, Journal of Hazardous Materials 239-240 (2012) 64-69. https://doi.org/10.1016/j.jhazmat.2012.03.029.

[37] Guedes-Alonso, R., Montesdeoca-Esponda, S., SosaFerreira, Z., Santana-Rodríguez, J. J., Liquid chromatography methodologies for the determination of steroid hormones in aquatic environmental systems, Trends in Environmental Analytical Chemistry 3-4 (2014) 14-27. https://doi.org/10.1016/j.teac.2014.10.001.

[38] Hamid, H., Eskicioglu, C., Fate of estrogenic hormones in wastewater and sludge treatment: A review of properties and analytical detection techniques in sludge matrix, Water Research $46 \quad$ (18) (2012) 5813-5833. https://doi.org/10.1016/j.watres.2012.08.002.

[39] Montagner, C. C., Jardim, W. F. Spatial and seasonal variations of pharmaceuticals and endocrine disruptors in the Atibaia River, São Paulo State (Brazil), Journal of the Brazilian Chemical Society 22 (8) (2011) 1452-1462. https://doi.org/10.1590/S0103-50532011000800008.

[40] Monteiro, B. R., Andrade, S. J., Desenvolvimento e validação de metodologia analítica para determi-nação dos hormônios sintéticos $17 \alpha$-etinilestradiol e levonorgestrel em águas superficiais, Ciência e Natura 37 (2) (2015) 391-400. https://doi.org/10.5902/2179460X17320.

[41] Moreira, D. S., Aquino, S. F., Afonso, R. J. C. F., Santos, E. P. P. C., Pádua, V. L. Occurrence of endocrine disrupting compounds in water sources of Belo Horizonte Metropolitan Area, Brazil. Environmental Technology 30 (10) (2009) 1041-1049. https://doi.org/10.1080/09593330903052830.

[42] Vulliet, E., Wiest, L., Baudot, R., Grenier-Loustalot, M.-F., Multi-residue analysis of steroids at sub-ng/L levels in surface and ground-waters using liquid chromatography coupled to tandem mass spectrometry, Journal of Chromatography A $1210 \quad$ (1) (2008) 84-91. https://doi.org/10.1016/j.chroma.2008.09.034.

[43] Bursch, W., Fuerhacker, M., Gemeiner, M., Grillitsch, B., Jungbauer, A., Kreuzinger, N., Moestl, E., Scharf, S., Schmid, E., Skutan, S., Walter, I., Endocrine disrupters in the aquatic environment: the Austrian approach - ARCEM, Water Science \& Technology 50 (5) (2004) 293-300. https://doi.org/10.2166/wst.2004.0340.

[44] Ghiselli, G., Jardim, W. F., Interferentes endócrinos no ambiente, Química Nova 30 (3) (2007) 695-706. https://doi.org/10.1590/S0100-40422007000300032.

[45] Daniel, M. S., Lima, E. C., Determinação simultânea de estriol, $\beta$-estradiol, $17 \alpha$-etinilestradiol e estrona empregandose extração em fase sólida (SPE) e cromatografia líquida de alta eficiência (HPLC). Revista Ambiente \& Água 9 (4) (2014) 688-695. https://doi.org/10.4136/ambi-agua.1346.

[46] Chaves, K. S., Determinação dos desreguladores endócrinos bisfenol-A, $\beta$-estradiol, 17 $\alpha$-etinilestradiol e estrona no Rio Paraíba do Sul. 133 p. Dissertação de mestrado - Escola de Engenharia de Lorena, Universidade de São Paulo, 2015. https://www.teses.usp.br/teses/disponiveis/97/97131/tde24032016-090046/publico/BID15010_C.pdf. 